\title{
Occurrence of aminoglycoside-modifying enzymes genes (aac(6')-I and ant(2")-I) in clinical isolates of Pseudomonas aeruginosa from Southwest Nigeria.
}

\author{
Bamidele Tolulope Odumosu ${ }^{1,2,3}$, Bolanle A Adeniyi ${ }^{2}$, Ram Chandra ${ }^{3}$
}

1. Department of Microbiology University of Lagos, Akoka Lagos.

2. Department of Pharmaceutical Microbiology, University of Ibadan, Nigeria.

3. Environmental Microbiology Section, Indian Institute of Toxicology Research, Lucknow, India.

\begin{abstract}
Background: Enzymatic modification of aminoglycosides is the primary mechanism of resistance by Pseudomonas aeruginosa.

Obejectives: We investigated the occurrence and mechanism of aminoglycosides resistance in P. aeruginosa isolates from hospitals in SouthWest Nigeria.

Methods: A total of 54 consecutive, non-duplicate clinical isolates of $\mathrm{P}$. aeruginosa were studied for the presence of aminoglycosides -modifying enzymes (AMEs) by PCR amplification and sequencing of genes encoding AMEs.

Results and conclusion: Two types of AME genes [aac (6') - I and ant (2") - I] were found in 12 isolates out of 54. Seven strains harboured one or more types of enzymes of which aac $\left(6^{\prime}\right)$ - I was the most frequently found gene $(10 / 54$ isolates, 18.5\%). None of the isolates investigated in this study were positive for aph, aac (3) and aac (6") - II genes. Prevalence of P. aeruginosa producing AME genes in this study may suggest aminoglycosides use in Nigeria. This study highlights need for functional antimicrobial surveillance system in Nigeria.

Keywords: Aminoglycoside-modifying enzymes, antibiotics resistance, Pseudomonas aeruginosa

DOI: http://dx.doi.org/10.4314/ahs.v15i4.29

Cite as: Odumosu BT, Adeniyi BA, Chandra R. Occurrence of aminoglycoside-modifying ensymes genes (aac $\left(6^{\prime}\right)-I$ and ant (2")-I) in clinical isolates of Pseudomonas aeruginosa from Southwest Nigeria. Afri Health Sci. 2015;15(4):1277-81. http://dx.doi.org/10.4314/abs. v15i4.29
\end{abstract}

\section{Introduction}

Pseudomonas aeruginosa is an adaptable Gram-negative rod-shaped bacterium found almost everywhere especially in moist places. It is an opportunistic human pathogen implicated in more hospital-acquired infections than community-acquired ones ${ }^{1}$. According to several scientific reports, P. aeruginosa is the main cause of ventilator-associated pneumonia, burn infections, and infections in cystic fibrosis patients ${ }^{2-4}$. This pathogen has been involved in several nosocomial infections such as bacteremia, urinary tract infections and endocarditis 5 . Treatment options for established Pseudomonal infections are always a difficult task due

\section{Corresponding author: \\ Bamidele Tolulope Odumosu, Department of Microbiology University of Lagos, Akoka Lagos \\ Email: deliniz@yahoo.com, \\ $\mathrm{Tel}+2348034515048$}

to its problematic multidrug resistance traits ${ }^{6}$. Antibiotic resistance characteristics in P. aeruginosa are both chromosomal and acquired or by horizontal transfer of resistance determinant often carried within plasmids and integrons ${ }^{7}$. Prescriptions for antipseudomonal drugs are combination therapy for effective synergy preventing the development of resistance in the course of treatments ${ }^{1}$.

Aminoglycosides are good antipseudomonal agents administered in combination therapy with $\beta$-lactams drugs ${ }^{1,8}$. P. aeruginosa resistance to aminoglycosides arises via enzymatic modification of the aminoglycosides by plasmid-or chromosome-encoded aminoglycosides -modifying enzymes (AMEs), impermeability, multidrug-active efflux systems and $16 \mathrm{~S}$ rRNA methylase genes ${ }^{9-11}$. Of these mechanisms, the enzymatic modification of aminoglycosides by plasmid or chromosome encoded genes is a more prevalent mechanism found in P. aeruginosa ${ }^{8}$. These modifying enzymes, aminoglycoside acetyltransferase (AAC), nucleotidyltransferase (ANT) and phosphotransferase (APH) are of clinical significance because their substrates includes the most important 
antipseudomonal aminoglycosides that are commonly prescribed $^{8}$. Spread of such genes especially in the hospital environment can further complicate treatments of infected individuals, hence a constant study and monitoring of resistance rate and patterns, of clinically important pathogens in our environment is of great significance. Information regarding the prevalence of these enzymes among clinical isolates of pathogenic bacteria are currently lacking in our region. Since amikacin and gentamicin are the most commonly prescribed aminoglycosides among antipseudomonas drugs in Nigeria, it is essential to carry out an investigation on the presence of these resistance genes among isolated strains of resistant P. aeruginosa in our hospitals. In this study, we reported the first detection of $\operatorname{aac}\left(6^{\prime}\right)-\mathrm{I}$ and ant $\left(2^{\prime \prime}\right)-\mathrm{I}$ AMEs from clinical isolates of multidrug resistant $\mathrm{P}$. aeruginosa from SouthWest Nigeria.

\section{Materials and method}

Bacterial isolates and antimicrobial susceptibility Fifty-four consecutive non-duplicated P. aeruginosa strains were collected from 5 hospitals (University College Hospital UCH, Catholic Hospital Oluyoro, Catholic Hospital Eleta , Federal Medical Centre Akure, Federal Medical Centre Abeokuta, 5- 20 isolates per centre) in SouthWest States of Nigeria between March to September 2010. Isolates were from different clinical samples (urine, wound swab, pus, ear swab, blood and vagina swab etc.). All the isolates were collected under approved ethical standards and verified using standard biochemical methods as described previously ${ }^{12}$. Antimicrobial susceptibility testing (AST) against amikacin, gentamicin, carbenicillin, piperacillin, ceftazidime, cefotaxime, ceftriaxone, ciprofloxacin (HiMedia India), was performed by disc diffusion technique and inter- preted according to the Clinical and Laboratory Standards Institute guidelines ${ }^{13}$. The Etest (HiMedia India) technique for the determination of minimum inhibitory concentration (MIC) was carried out according to the manufacturer's instructions. For quality control of the experiment P. aeruginosa ATCC 27853 and E.coli ATCC 25922 were used.

\section{PCR amplification}

The DNA template obtained from the supernatant of a boiled extracts of P. aeruginosa cells was used for PCR amplification as described previously ${ }^{14,15}$. PCR amplification was carried out in a volume of $25 \mu \mathrm{l}$ containing the following: $1-2 \mu \mathrm{l}$ DNA templates, $20 \mathrm{pM}$ of each primer, $250 \mu \mathrm{M}$ of dNTP, $10 \mathrm{mM}$ Tris- $\mathrm{HCl}$ (pH8.3), $50 \mathrm{mM} \mathrm{KCl}, 2.5 \mathrm{mM} \mathrm{MgCl} 2$ and $1.5 \mathrm{U}$ of Taq DNA polymerase (Promega Corporation, Madison, USA), using various annealing conditions for each primer set for the detection of various AME genes (aac(3)-I, aac(3)-II, $\operatorname{aac}\left(6^{\prime}\right)-\mathrm{I}, \operatorname{aac}\left(6^{\prime}\right)-\mathrm{II}$, ant $\left(2^{\prime \prime}\right)-\mathrm{I}$ and aph(3')-VI) 15 investigated in this study.

\section{Statistical analysis}

Statistical analysis was carried out using Statistical Package for Social Sciences (SPSS) software (version 11.5) for Windows ( $\mathrm{x}^{2}$-test). A P value of 0.05 was considered significant.

\section{Results}

Highest number of P. aeruginosa isolates was from urine $(38.9 \%)$ followed by wound $(20.4 \%)$, pus $(11.1 \%)$ and ear swab (9.3\%), while $5.6 \%, 5.5 \%, 3.7 \%, 3.7 \%$ and $1.8 \%$ isolates were from throat swab, blood, tracheal aspirate, HVS and leg ulcer respectively. Susceptibilities of the isolates and MIC ranges are summarized in Table 1.

\section{Table 1. Susceptibility of AME positive isolates to various antimicrobial agents}

\begin{tabular}{lccc}
\hline Agent/ $\mathbf{\mu g}$ & Percentage resistance & Percentage susceptibility & MIC range (ug/ml) \\
\hline Amikacin $/ 30$ & 41.66 & 58.33 & $\leq 0.1->256$ \\
Gentamicin/10 & 83.33 & 16.66 & $>256$ \\
Carbenicillin/100 & 83.33 & 16.66 & $\leq 5.0->240$ \\
Piperacillin/100 & 75.00 & 25.00 & $\leq 5.0->240$ \\
Ceftazidime/30 & 25.00 & 75.00 & $\leq 5.0-\geq 240$ \\
Cefotaxime/30 & 91.66 & 8.33 & $\leq 3.0->15.0$ \\
Ceftriaxone/30 & 100.00 & 0 & $>240$ \\
Ciprofloxacin/5 & 66.66 & 33.33 & $\leq 0.25->240$ \\
Levofloxacin/5 & 58.33 & 41.66 & $\leq 0.25->240$ \\
\hline
\end{tabular}


Highest resistance was observed for ceftriaxone $(100 \%)$, cefotaxime $(91.66 \%)$, followed by carbenicillin $(83.33 \%)$, gentamicin $(83.33 \%)$, piperacillin $(75.00 \%)$ and moderately to ciprofloxacin (66.66\%), levofloxacin (58.33\%), amikacin (41.66\%) and ceftazidime (25\%).
Resistance among the isolates was distributed across the hospitals.

The relationship between AME positive isolates sources and distributions are represented in Table 2.

Table 2. Relationships between isolates sources, distributions and their respective $\mathrm{AME}$ genes

\begin{tabular}{|c|c|c|c|c|c|}
\hline \multirow[t]{2}{*}{ Strain I.D } & \multirow[t]{2}{*}{ Source } & \multirow{2}{*}{$\begin{array}{l}\text { Patient } \\
\text { Age/sex }\end{array}$} & \multirow[t]{2}{*}{ Hospital } & \multicolumn{2}{|c|}{ AMEs detected } \\
\hline & & & & $\operatorname{aac}\left(6^{\prime}\right)-I$ & $\operatorname{aac}\left(6^{\prime}\right)-1$ \\
\hline ODM 5 & Pus & 28 Male & Eleta & + & + \\
\hline ODM 8 & Wound & 35 Female & $\mathrm{UCH}$ & + & + \\
\hline ODM 17 & Urine & 28 Female & Eleta & + & + \\
\hline ODM 24 & Urine & 26 Male & Oluyoro & + & + \\
\hline ODM 25 & Urine & 21 Female & $\mathrm{UCH}$ & + & - \\
\hline ODM 32 & Wound & 32 Female & $\mathrm{UCH}$ & + & + \\
\hline ODM 34 & Vaginal & 30 Female & FMC & + & + \\
\hline ODM 38 & Urine & 29 Female & Oluyoro & + & + \\
\hline ODM 40 & Vaginal & 30 Female & $\mathrm{UCH}$ & + & - \\
\hline ODM 45 & Wound & 38 Female & Oluyoro & - & + \\
\hline ODM 48 & Urine & 43 Male & Oluyoro & + & - \\
\hline ODM 49 & Urine & 12 Male & $\mathrm{UCH}$ & - & + \\
\hline
\end{tabular}

The PCR result gave two types of AME genes aac (6') - I and ant (2") - I in $12(22.2 \%)$ out of the 54 isolates investigated and aac $\left(6^{\prime}\right)$ - I was the most frequently found gene in $10(18.5 \%)$ isolates. Seven $(12.9 \%)$ isolates harboured both aac $\left(6^{\prime}\right)-\mathrm{I}$ and ant $\left(2^{\prime \prime}\right)$ - I genes (Table 3). None of the isolates investigated in this study were positive for aph, aac (3) and aac (6") - II genes. The aac (6') - I and ant (2") - I genes had statistically significant association with amikacin and gentamicin resistance individually ( $\mathrm{x} 2$ test, $\mathrm{p} \leq 0.02$ ), while susceptibility was retained in the presence of at least one AME gene in 3 isolate.

Table 3. Prevalence of AMEs and correlation between antibiograms and AME genes in aminoglycoside resistant $P$. aeruginosa isolates

\begin{tabular}{|c|c|c|c|}
\hline $\begin{array}{l}\text { PCR results of } \\
\text { AME genes }\end{array}$ & $\begin{array}{l}\text { No. Of } \\
\text { isolates }(\%)\end{array}$ & $\begin{array}{l}\text { Expected } \\
\text { resistance }\end{array}$ & $\begin{array}{l}\text { Observed result of aminoglycosides resistance } \\
\text { phenotypes (no of isolates) }\end{array}$ \\
\hline$a a c\left(6^{\prime}\right)-1$ & $10(18.5)$ & $\mathrm{AMK}$ & $\begin{array}{l}\text { Unexpected resistance to GEN (3) } \\
\text { As expected (7) }\end{array}$ \\
\hline $\operatorname{ant}\left(2^{\prime \prime}\right)-1$ & $9(16.6)$ & GEN & $\begin{array}{l}\text { Unexpected resistance to } \operatorname{AMK}(1) \\
\text { As expected (8) }\end{array}$ \\
\hline $\operatorname{aac}\left(6^{\prime}\right)-I+\operatorname{ant}\left(2^{\prime \prime}\right)-I$ & $7(12.9)$ & AMK, GEN & $\begin{array}{l}\text { Unexpected susceptibility to AMK (1) } \\
\text { Unexpected susceptibility to GEN (1) } \\
\text { Unexpected susceptibility to AMK+ GEN (1) } \\
\text { As expected (4) }\end{array}$ \\
\hline
\end{tabular}




\section{Discussion}

Aminoglycosides is a class of antibiotics with wide acceptance because of their stability against many resistant bacteria ${ }^{16}$. This study describes the carriage of AMEs among multidrug resistant clinical isolates of P. aeruginosa. The frequency of AME genes detected from clinical isolates of $\mathrm{P}$. aeruginosa from different countries varies. The $22.2 \%$ incidence rate of AME genes observed in this study is lower than previously reported rate of $80 \%$ from Greece ${ }^{17}, 87.3 \%$ from Korea $^{15}, 43.5 \%$ from India ${ }^{18}$, and 54\% from Iran ${ }^{19}$. Out of the three classes of AMES (aph, aac and ant) investigated in this study, only aac( $\left(6^{\prime}\right)-\mathrm{I}$ and ant(2")-I genes were detected while aac $\left(6^{\prime}\right)$ - I was the most frequent. This is in line with previous studies conducted in Belgium, Greece, France and India, where aac $\left(6^{\prime}\right)$-I was the most frequently detected AME genes ${ }^{9,18,20}$ but is in sharp contrast to studies conducted in USA, Korea and Iran where the most common AME gene detected were aac $\left(6^{\prime}\right)$-II and aph ( $\left.3^{\prime}\right)-\mathrm{IV}^{9,15,19}$. It has been previously reported that the occurrence of these combination of enzymes varied by geographic regions and among hospitals ${ }^{9}$, this suggests a reason for differences in our result and other findings. Consistent with other previous studies that reported co-habitation of one or more AME genes in a single $P$. aeruginosa isolates ${ }^{9,15,19}, 12.9 \%$ of $\mathrm{P}$. aeruginosa isolates in this study harbours both $\operatorname{aac}\left(6^{\prime}\right)-\mathrm{I}$ and ant $\left(2^{\prime \prime}\right)-\mathrm{I}$ genes and they were distributed among the selected hospitals (Table 1).

According to previous reports ${ }^{8,20,21}$, the presence of aac $\left(6^{\prime}\right)$-I gene in an organism is significant for amikacin resistance while ant( $(2 ")-\mathrm{I}$ is responsible for the inactivation of gentamicin. However, in this present study we observed unexpected resistance phenotypes in some of the isolates that is contrary to our antimicrobial susceptibility test (AST) and PCR amplification of AMEs results. For instance 3 of the isolates harbouring aac $\left(6^{\prime}\right)$-I gene which has been reported to have amikacin as a substrate showed resistance to gentamicin while one isolate showed susceptibility to both drugs in spite of the presence of both AME genes. We couldn't identify the reason for the latter but we believe the presence of undetectable genes located at the integrons of these isolates as was reported in our previous study ${ }^{14}$ or other resistance mechanisms such as efflux pumps might be the reasons for the former. Similar observations have also been reported from other studies ${ }^{15,19}$, where several AME PCR results did not correlate with the AST. Detection of AMEs is a useful tool especially among clinical isolates because the genes for the aminoglyco- side-modifying enzymes are transferable and are often located on plasmids or transposons along with genes encoding resistance to other classes of antibacterials. Our study has not identified the transferability of the AME genes among isolates or the spread of few strains carrying these genes, this however requires further investigation. Unabated spread of AMEs in developed countries due to the use of aminoglycoside has been a clinical challenge for over two decades; however, incidence of these genes in Nigeria is highly disturbing because there are no functional antimicrobial resistance surveillance programmes available in Nigeria. Data on the aminoglycoside mechanisms of resistance by P. aeruginosa in Nigeria is currently lacking. To our knowledge, this is the first report of detection of AMEs genes in clinical P. aeruginosa isolates from Nigeria.

\section{Conclusion}

In summary, this study reports $22.2 \% \mathrm{P}$. aeruginosa isolates harbouring aac $\left(6^{\prime}\right)-\mathrm{I}$ and ant(2")-I AMEs genes from the investigated hospitals in SouthWestern Nigeria. Considering the fact that aminoglycosides are good antipseudomonal prescribed for the treatments of Pseudomonal infections, unabated spread of AME genes especially in our region is worrisome .Constant monitoring of aminoglycosides modifying genes is necessary considering their co-selection and easy dissemination among multidrug resistant bacteria. A call for a functional antimicrobial resistance surveillance programme in Nigeria is of necessity.

\section{Conflict of interest}

None declared.

\section{Acknowledgements}

This study was supported by TWAS/CSIR PG Fellowship for Bamidele Odumosu.

\section{References}

1. Lister PD, Wolte, DJ, Hanson ND (2009). Antibacterial-resistant Pseudomonas aeruginosa: clinical impact and complex regulation of chromosomally encoded resistance mechanisms. Clin. Microbiol. Rev. 22, 582-610.

2. Aloush V, Navon-Venezia S, Seigman I, Cabili S, Carmeli, Y (2006). Multidrug-Resistant Pseudomonas aeruginosa: Risk Factors and Clinical Impact Antimicrob Agent Chemother. 50, 43-48.

3. Rello J, Allegri C, Rodriguez A Vidaur L, Sirgo G, Gomez F et al. (2006). Risk factors for ventilator associated pneumonia by Pseudomonas aeruginosa in pres- 
ence of recent antibiotic exposure. Anesthesiology. 105: 709-14.

4. Otaibi FE, Al-Hulaily FF (2012). Imipenem-resistant Psedomonas aeruginosa: Epidemiology and susceptibility patterns at a Teaching Hospital in Riyadh, Saudi Arabia. Afr. J. Microbiol. Res. 6, 1527 - 1533

5. Richards MJ, Edwards JR, Culver DH, Gaynes RP (1999). Nosocomial infections in medical intensive care units in the United States. Crit. Care Med. 27, 887-892.

6. Dimatatac EL, Alejandria MM, Montalban C, Pineda C, Ang C, Delino RL (2003). Clinical outcomes and costs of care of antibiotic resistant Pseudomonas aeruginosa infections. Phil. J. Microbiol. Infect. Dis. 32, 159-167.

7. Dubois V, Poirel L, Marie C, Arpin C, Nordmann P, Quentin C (2002). Molecular characterization of a novel class 1 integron containing blaGES-1 and fused product of aac(3)-Ib/aac(69-Ib9 gene cassettes in Pseudomonas aeruginosa. Antimicrob Agents Chemother. 46, 638-645.

8. Poole K (2005a). Aminoglycoside resistance in Pseudomonas aeruginosa. Antimicrob Agents Chemother 49, 479-487.

9. Miller GH, Sabatelli FJ, Hare RS, Glupczynski Y, Mackey P, Shlaes, D et al (1997). The most frequent aminoglycoside resistance mechanisms - changes with time and geographic area: a reflection of aminoglycoside usage patterns? Aminoglycoside Resistance Study Groups. Clin Infect Dis. 24, 46-62.

10. Poole K (2005). Efflux-mediated antimicrobial resistance. J Antimicrob Chemother 56, 20-51.

11. Doi Y and Arakawa Y (2007). 16S ribosomal RNA methylation: emerging resistance mechanisms against aminoglycosides. Clin Infect Dis 45, 88-94.

12. Murray PR, Baron EJ, Jorgensen JH, Landry ML, Pfaller MA (2003). Manual of Clinical Microbiology. 8th edition. Washington DC: ASM Press.

13. CLSI: Performance standards for antimicrobial susceptibility testing; 20th informational supplement. M100-S20. Wayne, Pa: Clinical and Laboratory Standards Institute; 2010.

14. Odumosu BT, Adeniy, BA, Chandra R (2013). Analysis of integrons and associated gene cassettes in clinical isolates of multidrug resistant Pseudomonas aeruginosa from Southwest Nigeria. Annals Clin Microbiol Antimicrob. 12, 29-36

15. Kim JY, Park YJ, Kwon HJ, Han K, Kang MW, Woo GJ (2008). Occurrence and mechanisms of amikacin resistance and its association with beta-lactamases in Pseudomonas aeruginosa: a Korean nationwide study. J Antimicrob Chemother. 62, 479-483.

16. Falagas ME, Grammatikos AP, Michalopoulos A (2008). Potential of old-generation antibiotics to address current need for new antibiotics. Expert Rev Anti Infect Ther. 6, 593-600.

17. Žáková A, Talábová E, Giamarellou H, Mačičková T, Michálková-Papajová D, Bagová M et al. (2001). Comparison of aminoglycoside resistance mechanisms in Pseudomonas aeruginosa isolates from Slovakia and Greece. Biologia, Bratislava. 56, 617-23.

18. Chaudhary M, and Payasi A (2014). Resistance Patterns and Prevalence of the Aminoglycoside Modifying Enzymes in Clinical Isolates of Gram Negative Pathogens. Global J. Pharmacol. 8, 73-79.

19. Vaziri F, Peerayeh SN, Nejad QB, Farhadian A (2011). The prevalence of aminoglycoside-modifying enzyme genes (aac (6')-I, aac (6')-II, ant (2")-I, aph (3')VI) in Pseudomonas aeruginosa. Clinics. 66, 1519-1522. 20. Vakulenko SB Mobashery S (2003). Versatility of Aminoglycosides and Prospects for Their Future. Clin. Microbiol. Rev. 16, 430-50.

21. Shaw KJ, Rather PN, Hare RS, Miller GH (1993). Molecular Genetics of Aminoglycoside Resistance Genes and Familial Relationships of the Aminoglycoside-Modifying Enzymes. Microbiological Reviews. 57, 138-163. 